\title{
ISOLASI DAN IDENTIFIKASI FLAVONOID DARI \\ DAUN DEWANDARU (Eugenia uniflora L.)
}

\section{ISOLATION AND IDENTIFICATION OF FLAVONOIDS FROM DEWANDARU (Eugenia uniflora L.) LEAF}

\author{
Andi Suhendi ${ }^{\star}$, Landyyun Rahmawan Sjahid, Dedi Hanwar \\ Fakultas Farmasi, Universitas Muhammadiyah Surakarta \\ andfa@yahoo.com
}

\begin{abstract}
ABSTRAK
Dewandaru (Eugenia uniflora L.) secara tradisional digunakan sebagai penurun panas dan sakit perut. Penelitian membuktikan aktivitas biologis dewandaru sebagai antibakteri, antidiabetes, dan antioksidan. Senyawa yang diduga bertanggungjawab adalah flavonoid. Penelitian ini dilakukan untuk mengetahui jenis senyawa flavonoid yang terdapat dalam daun dewandaru (Eugenia uniflora L.). Ekstraksi dilakukan dua tahap yaitu tahap penghilangan lemak dengan metode sokletasi menggunakan pelarut kloroform dan tahap kedua maserasi dengan etanol $70 \%$. Ekstrak difraksinasi dengan etil asetat dan air, kemudian fraksinya diperiksa dengan KLT menggunakan fase gerak asam asetat 15\% dan BAW. Fraksi etil asetat diisolasi dengan KLT preparatif. Bercak pita yang memiliki harga Rf dan warna yang sama dengan deteksi awal diambil dan disari. Kemudian dianalisis menggunakan spektrofotometer UV-Vis, pereaksi diagnostic $\mathrm{NaOH}, \mathrm{NaOAC}, \mathrm{H}_{3} \mathrm{BO}_{3}, \mathrm{AlCl}_{3}, \mathrm{HCl}, \mathrm{KLT}$ dua dimensi, hidrolisis isolat fraksi etil asetat. Berdasarkan pergeseran panjang gelombang spektra UV-Vis dengan dan tanpa pereaksi diagnostik serta uji $K L T$ didapatkan struktur parsial yang diduga kuat 5,7,3',4'-tetra hidroksi flavonol atau kuersetin.
\end{abstract}

Kata Kunci : dewandaru (Eugenia uniflora L.), flavonoid, KLT, spektrofotometer UV-Vis.

\section{ABSTRACT}

Dewandaru (Eugenia uniflora L.) traditionally used as antipyretic and stomachache. Based on research it is also has the effect as antibacterial, anti diabetic, and antioxidant. The chemical compounds which responsible are flavonoids. This research is conducted to know flavonoid compound in dewandaru (Eugenia uniflora L.) leaf. Dewandaru (Eugenia uniflora L.) leaf dust be defatted by chloroform then be macerated by ethanol 70\%. Extract thick in fractionation with ethyl acetate and water, and flavonoids examined using TLC by acetic acid $15 \%$ and BAW as mobile phase. An ethyl acetate fraction was separated in BAW with Rf 0.75 is yellow gloomy fluorescence under $U V_{366} \mathrm{~nm}$ before steam of ammonia and become yellow after steam of ammonia was selected. Ethyl acetate fraction isolated with preparative thin layer chromatography. Spot have the same value of Rf and colour with early detection taken. The spot dissolved by methanol and analyzed with two dimensional TLC and determined by spectrophotometer and diagnostic reagent $\mathrm{NaOH}, \mathrm{NaOAc}, \mathrm{H}_{3} \mathrm{BO}_{3}, \mathrm{AlCl}_{3}$, dan $\mathrm{HCl}$. Based on spectra profile with and without diagnostic reagent and TLC assay the partial structure of isolate is strongly suspected 5,7,3', 4'-tetra hydroxyl flavonol or quercetin.

Key Word : dewandaru (Eugenia uniflora L.), flavonoids, TLC, UV-Vis spectrophotometer.

\section{PENDAHULUAN}

Daun dan buah dewandaru secara empiris digunakan sebagai obat penurun panas dan sakit perut (Morton, 1987). Aktivitas biologis ekstrak dewandaru diantaranya adalah antibakteri (Khotimah, 2004) dan antioksidan (Einbond et al, 2004). Daun dewandaru dapat berfungsi sebagai antiradikal yang disebabkan karena adanya senyawa flavonoid (Reynertson and Kennelly, 2001; Utami, dkk., 2005). Kandungan kimia dewandaru adalah saponin, tannin, vitamin C, senyawa atsiri seperti sineol, sitronela, sesquiterpen, flavonoid, dan antosianin (Einbond et al, 2004; Hutapea, 91). Kandungan yang lebih spesifik adalah miristin, kuersetin (Schmeda-Hirschmann et al, 1987; Haron et al, 1992) dan kaemferol (Haron et al., 1992)

Isolasi dilakukan untuk mendapatkan isolat-isolat suatu senyawa atau sehingga dapat mempermudah untuk melakukan identifikasi senyawa-senyawa yang terdapat dalam simplisia. Identifikasi terhadap isolate diperlukan untuk mengetahui jenis senyawa flavonoid. 


\section{METODE PENELITIAN}

Alat : perangkat penyari soxhlet, heating mantel, vacuum dryer, rotary evaporator (Hunderbolt co.), corong buchner, cawan porselen, perangkat KLT, spektrofotometer UV mini 1240 Shimadzu (Shimadzu co.), mini spin, corong pisah, alat-alat gelas.

Bahan : serbuk daun dewandaru, kloroform p.a (E. Merck), etanol $70 \%$ p.a (Bratachem), metanol p.a (E. Merck), aquadest, pereaksi sitroborat, etil asetat p.a (E. Merck), asam asetat $15 \% \mathrm{v} /$ p.a. (E. Merck), BAW (ButanolAsam asetat-Air, 4:1:5 lapisan atas), uap ammonia, natrium asetat (NaOAc) p.a (Merck), natrium hidroksida $(\mathrm{NaOH}) 2 \mathrm{~N}$, alumunium klorida $\left(\mathrm{AlCl}_{3}\right)$ p.a. (Sigma co.), asam klorida $(\mathrm{HCl}) 2 \mathrm{~N}$, asam borat $\left(\mathrm{H}_{3} \mathrm{BO}_{3}\right)$ p.a (E. Merck), kertas saring, alumunium foil, tabung effendorf.

\section{Jalan Penelitian}

Sebanyak 50 gram serbuk daun dewandaru ditimbang, diawalemakkan menggunakan alat soxhlet dengan penyari kloroform paling sedikit $2 x$ sirkulasi dan ditambah batu didih untuk meratakan panas. Penyarian dilakukan hingga penyari yang terkumpul di tampungan (sifon) tidak berwarna lagi. Serbuk diambil dan dikeringkan.

Serbuk dimaserasi dengan etanol $70 \%$ selama 3 hari dan dilakukan remaserasi hingga penyari jernih. Ekstrak disaring dan diuapkan dengan rotary evaporator dan vacuum dryer hingga menjadi kental.

Ekstrak kental ditambah $15 \mathrm{~mL}$ air dan dipartisi dengan $15 \mathrm{~mL}$ etil asetat. Fraksi dilakukan beberapa kali, fraksi air dan etil asetat dipisahkan dan dikumpulkan menjadi satu.

Masing-masing fraksi ditotolkan pada plat KLT fase diam selulosa dan dielusi dengan asam asetat 15\% $\mathrm{v} / \mathrm{v}$ dan BAW (Butanol:Asam asetat glasial:Air, 4:1:5 lapisan atas). Fase gerak yang baik untuk pemisahan flavonoid digunakan untuk langkah berikutnya. Deteksi awal adanya flavonoid dilakukan di bawah $U V_{366} \mathrm{~nm}$ sebelum dan sesudah diuapi ammonia. Setelah uap ammonia hilang, kemudian disemprot dengan pereaksi sitroborat dan dipanaskan pada $110^{\circ} \mathrm{C}$ selama 5 menit, dilihat dibawah $\mathrm{UV}_{366} \mathrm{~nm}$.

Fraksi yang terdeteksi bercak flavonoid dilanjutkan isolasi dengan KLT preparatif, yaitu KLT yang penotolannya berbentuk pita, dengan fase gerak BAW. Bercak yang berfluoresensi kuning redup pada $U V_{366} \mathrm{~nm}$ dan berwarna kuning saat diuapi ammonia, dikerok, dikumpulkan kemudian diekstraksi dengan pelarut metanol. Kemudian disentrifugasi dengan $3500 \mathrm{rpm}$ selama 10 menit untuk memisahkan isolat dengan serbuk selulosa.
Kemurnian isolat flavonoid yang diperoleh, diperiksa menggunakan kromatografi lapis tipis dua dimensi. Isolat ditotolkan pada salah satu ujung plat KLT fase diam selulosa dengan jarak elusi $10 \times 10 \mathrm{~cm}$ dan dielusi dengan fase gerak asam asetat $15 \%$ dan dilanjutkan dengan BAW $(4: 1: 5 \mathrm{v} / \mathrm{v}$ lapisan atas). Adanya bercak tunggal menunjukkan bahwa isolat telah murni.

Identifikasi Isolat Flavonoid (Mabry et al, 1970; Markham, 1988)

\section{Tahap I}

Larutan isolat dalam metanol dituang ke kuvet (2-3 ml larutan sampel) direkam spektranya pada $\lambda 200-500 \mathrm{~nm}$.

\section{Tahap II :}

Larutan isolat dalam metanol ditambah 3 tetes larutan $\mathrm{NaOH} 2 \mathrm{~N}$, dicampur, direkam spektranya. Setelah 5 menit dilakukan perekaman kembali untuk mengetahui kemungkinan terjadinya dekomposisi flavonoid.

\section{Tahap III :}

Larutan isolat flavonoid dalam metanol ditambah 3 tetes $\mathrm{AlCl}_{3}$, dicampur, direkam spektranya.

\section{Tahap IV :}

Larutan tahap III ditambah 3 tetes $\mathrm{HCl}$, dicampur, direkam spektranya.

Tahap V :

Larutan isolat dalam metanol ditambah $\mathrm{NaOAc}$, dicampur, direkam spektranya.

\section{Tahap VI :}

Larutan tahap $\mathrm{V}$ ditambah asam borat $\left(\mathrm{H}_{3} \mathrm{BO}_{3}\right)$, dicampur, direkam spektranya.

Larutan isolat dalam metanol diuapkan hingga volume $2 \mathrm{ml}$ dan dihidrolisis dengan $\mathrm{HCl}$ $2 \mathrm{~N}$, direfluks pada suhu $100^{\circ} \mathrm{C}$ selama 1 jam. Setelah dingin, difraksinasi dengan etil asetat. Hasil fraksinasi diuapkan, dilarutkan dalam metanol dan digunakan untuk uji aglikon dengan ditotolkan pada plat KLT fase diam selulosa dan dilakukan kromatografi dengan fase gerak BAW disamping larutan isolat yang belum dihidrolisis. Selanjutnya bercak dideteksi menggunakan $\mathrm{UV}_{366} \mathrm{~nm}$ sebelum dan sesudah diuapi ammonia (Markham, 1988).

Data berupa Rf, warna bercak kromatografi lapis tipis dan spektra pergeseran panjang gelombang dengan spektrofotometer UV-Vis dianalisis berdasarkan pustaka acuan.

\section{HASIL DAN PEMBAHASAN}

Proses isolasi suatu senyawa tertentu dipengaruhi oleh tahap ekstraksi. Ekstrak yang dihasilkan dari proses awal harus menghasilkan kelompok senyawa yang dituju, dalam hal ini senyawa-senyawa polar. Oleh Karena itu proses ekstraksi dilakukan dua tahap yaitu penghilangan senyawa yang tidak diharapkan 
adalah senyawa non polar, eliminasi dilakukan dengan sokletasi menggunakan pelarut kloroform. Tahap kedua ekstraksi yang ditujukan untuk mengambil senyawa polar dengan optimal dan etanol $70 \%$ merupakan pelarut yang polar akan menyari dengan baik senyawa yang diharapkan.

Fraksinasi merupakan tahap kedua dalam proses isolasi. Fraksinasi yang sederhana dan mudah adalah metode partisi. Pelarut etil asetat digunakan untuk menarik senyawa flavonoid semi polar dan air digunakan untuk menarik senyawa polar. Uji kualitatif terhadap fraksi menunjukkan bahwa fraksi air tidak terdeteksi flavonoid dan fraksi etil asetat mengandung flavonoid yang ditandai dengan adanya spot kuning redup yang brfluoresensi kuning lemah (Gambar 1).

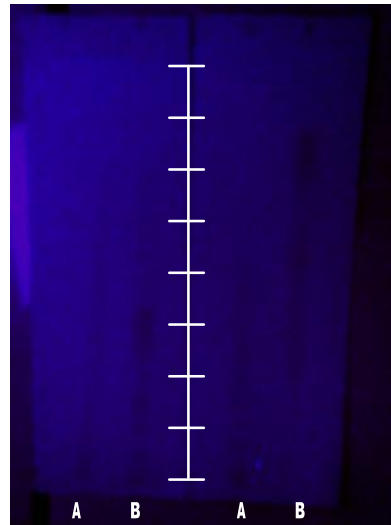

Fg : As.Aset 15\%

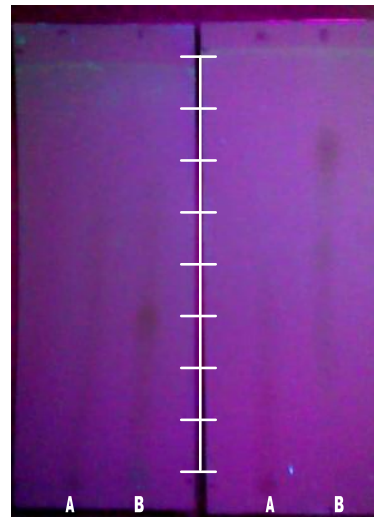

$\mathrm{Fg}: \mathrm{BAW}$
Keterangan :

A : Fraksi Air

B : Fraksi Etil Asetat

Gambar1- Kromatogram Uji Kualitatif

Berdasarkan Gambar 1, didapatkan pemisahan yang baik dengan fase gerak BAW (4:1:5 lapisan atas). Hal ini terlihat dari Rf hasil pemisahan flavonoid dengan fase gerak BAW
(Rf 0,75 ) lebih tinggi dibandingkan pemisahan dengan fase gerak asam asetat 15\% (Rf 0,125).

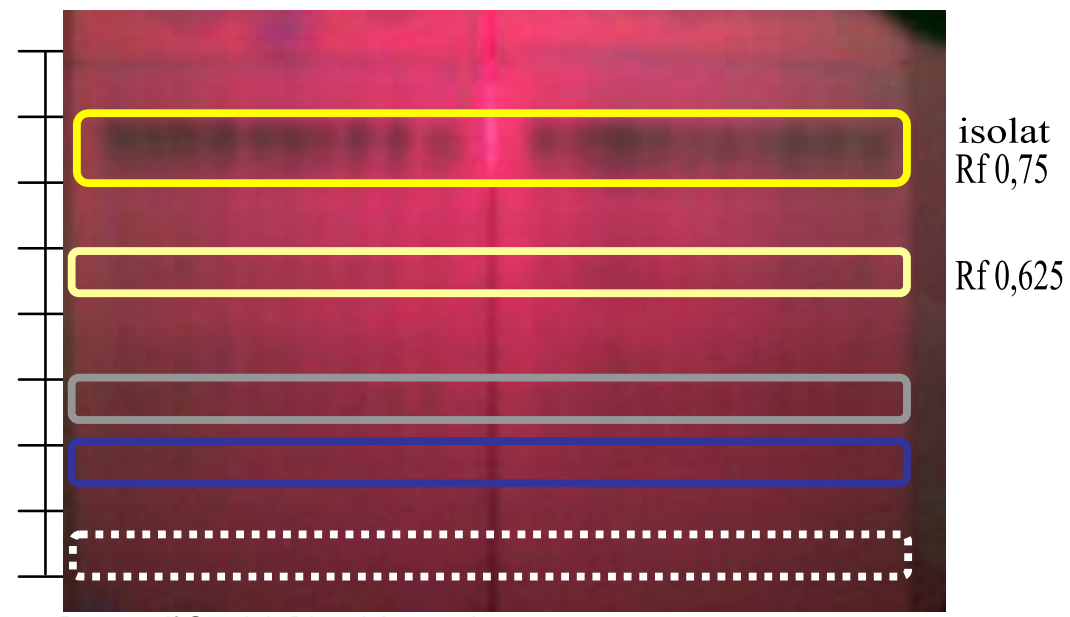

Gambar2- Kromatogram Preparatif Setelah Diuapi Ammonia

Hasil elusi fraksi etil asetat denganKLT preparatif didapatkan dua bercak yang memiliki flavonoid positif Rf 0,75 dan Rf 0,625 (Gambar 2). Intensitas warna yang lebih kuat adalah bercak dengan Rf 0,75, sehingga bercak ini dilanjutkan untuk proses berikutnya. Bercak pada Rf 0,75 dievaluasi kemurniannya dengan menggunakan KLT dua dimensi. Hasil yang diperoleh menunjukkan adanya bercak tunggal menunjukkan bahwa isolat telah murni.

\section{Identifikasi Isolat Flavonoid}

Identifikasi dilakukan dengan pengamatan perubahan panjang gelombang pada spektra flavonoid menggunakan spektrofotometer UV-Vis. Spektra flavonoid terdiri dari dua absorbsi maksimal yaitu pada range 240-285 $\mathrm{nm}$ (pita I) dan pada range 300$550 \mathrm{~nm}$ (pita II). Sedangkan untuk mengetahui adanya gugus tambahan yang melekat pada gugus utama flavonoid digunakan pereaksi diagnostik yang memiliki reaksi khusus sehingga dapat diketahui berdasar pergeseran panjang gelombang $(\lambda)$ maksimalnya. 


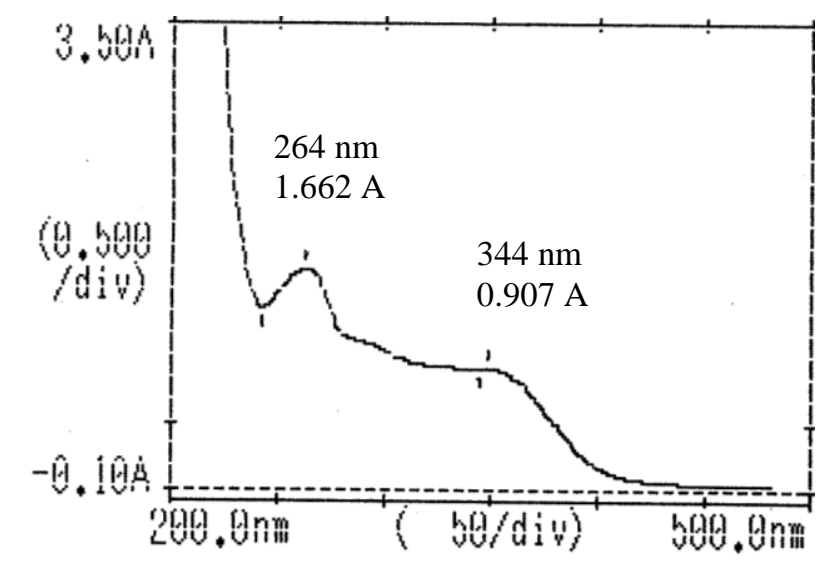

Gambar 3-Spektra Awal Isolat Flavonoid

Berdasarkan Gambar 3, didapatkan bahwa isolat flavonoid memperlihatkan spektra awal yang terletak pada $344 \mathrm{~nm}$ (pita I) dan 264 nm (pita II) yang menunjukkan gugus utama berupa flavon atau flavonol 3-OH tersubstitusi.

Keberadaan gugus hidroksi dikonfirmasi dengan pereaksi diagnostik $\mathrm{NaOH} 2 \mathrm{~N}$. Pada umumnya senyawa flavonol akan mengalami pergeseran batokromik karena memiliki gugus hidroksil. $\mathrm{NaOH}$ bereaksi dengan mengionisasi semua gugus hidroksil bebas yang terdapat dalam senyawa flavonoid.

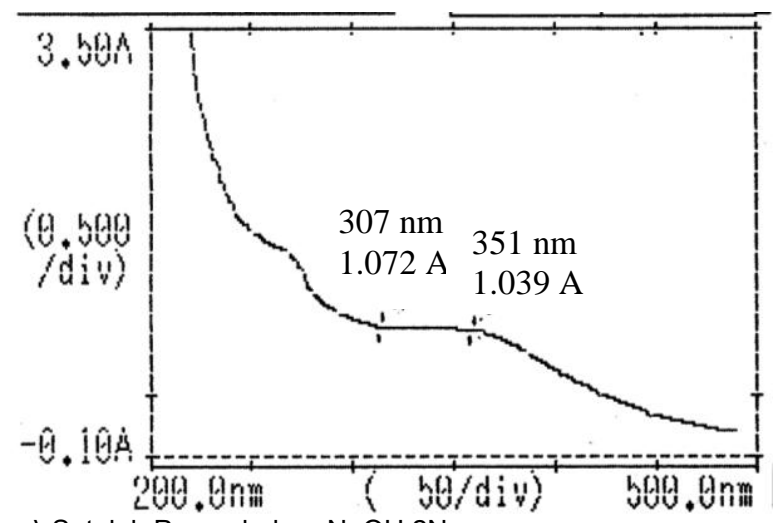

Gambar 4- Spektra Pergeseran $\lambda$ Setelah Penambahan $\mathrm{NaOH} 2 \mathrm{~N}$

Berdasarkan Gambar 4, terbukti terjadi pergeseran batokromik pada semua pita. Namun letak gugus hidroksil pada posisi dimana belum dapat dipastikan karena pergeseran yang terjadi belum mencapai range yang ditentukan. Tetapi dari hasil tersebut dapat diperkirakan adanya gugus hidroksil yang cukup kuat pada cincin A yang ditunjukkan oleh pergeseran batokromik yang cukup besar (43 nm) pada pita II dan terdapat pula gugus hidroksil pada cincin B yang ditunjukkan oleh pergeseran batokromik walaupun tidak terlalu besar.

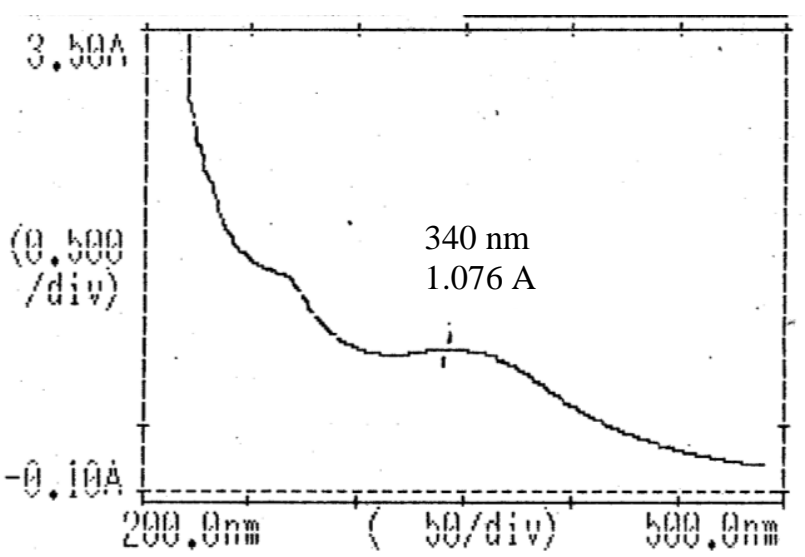

Gambar 5- Spektra Pergeseran $\lambda$ Setelah Penambahan $\mathrm{NaOH} 2 \mathrm{~N}, 5^{\prime}$ 
Reaksi isolat dengan pereaksi diagnostic $\mathrm{NaOH}$ ditunggu selama 5 menit untuk untuk mengetahui adanya dekomposisi flavonoid yang ditunjukkan dengan penurunan absorbansi. Tetapi dari spectra yang tampak pada Gambar 5, tidak dapat diketahui hasilnya karena pita II tidak teramati.

Pereaksi diagnostik lainnya adalah $\mathrm{AlCl}_{3}$ yang akan membentuk kompleks dengan orto dihidroksi maupun hidroksi keton. Sedangkan pada penambahan $\mathrm{HCl}$ akan mengurai kembali kompleks karena Al tak stabil yang terbentuk pada o-di OH. Spektra (gambar 6) memperlihatkan bahwa terjadi pergeseran batokromik pita I sebesar $65 \mathrm{~nm}$ pada penambahan $\mathrm{AlCl}_{3}$ yang menunjukkan adanya kompleks yang terbentuk dari hidroksi keton (3-OH dengan atau tanpa $5-\mathrm{OH}$ ) dan atau o-di $\mathrm{OH}$.

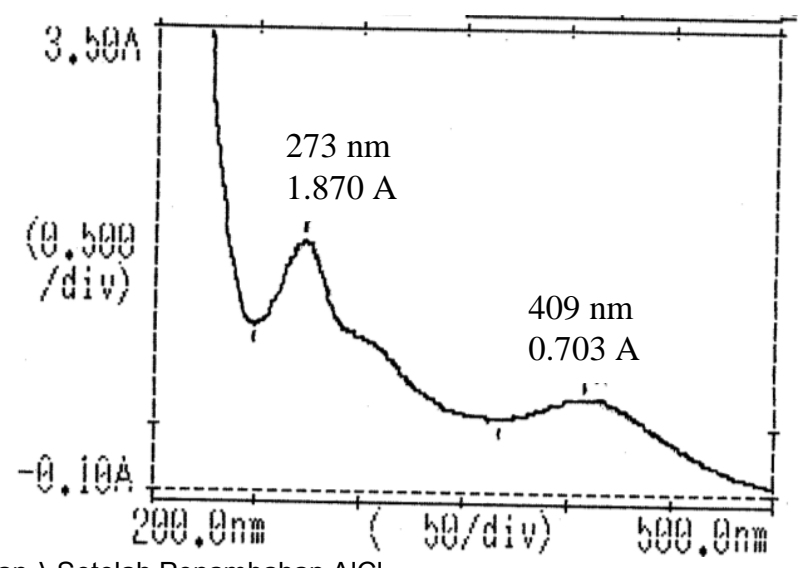

Gambar 6- Spektra Pergeseran $\lambda$ Setelah Penambahan $\mathrm{AICl}_{3}$

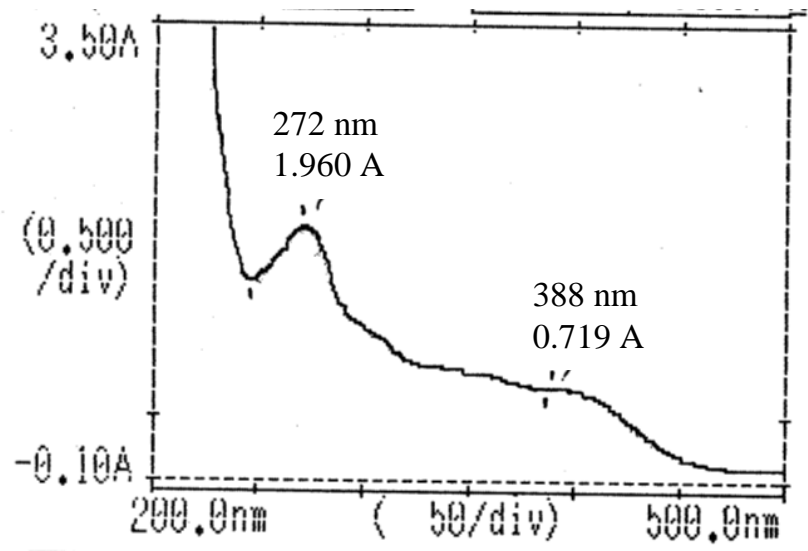

Gambar 7- Spektra Pergeseran $\lambda$ Setelah Penambahan $\mathrm{AlCl}_{3} / \mathrm{HCl}$

Sedangkan pada reaksi penambahan $\mathrm{HCl}$ terjadi pergeseran hipsokromik pita I sebesar $21 \mathrm{~nm}$ dari penambahan $\mathrm{AlCl}_{3}$, menunjukkan adanya kompleks yang terurai. Hasil tersebut menunjukkan adanya gugus o-di $\mathrm{OH}$. Dari hasil tersebut juga dapat diketahui bahwa di dalam struktur terdapat gugus $3-\mathrm{OH}$ dan atau $5-\mathrm{OH}$ yang ditunjukkan pergeseran batokromik pada penambahan $\mathrm{AlCl}_{3} / \mathrm{HCl}$ dibandingkan dengan spektra awal sebesar 44 nm pada Gambar 7.
Pereaksi diagnostik selanjutnya adalah $\mathrm{NaOAc}$ yang hanya bereaksi dengan mengionisasi gugus hidroksil flavonoid yang paling tahan asam yaitu gugus 7-OH. Gugus 7$\mathrm{OH}$ akan terionisasi menjadi 7-ONa dan menyebabkan terjadinya pergeseran batokromik. 


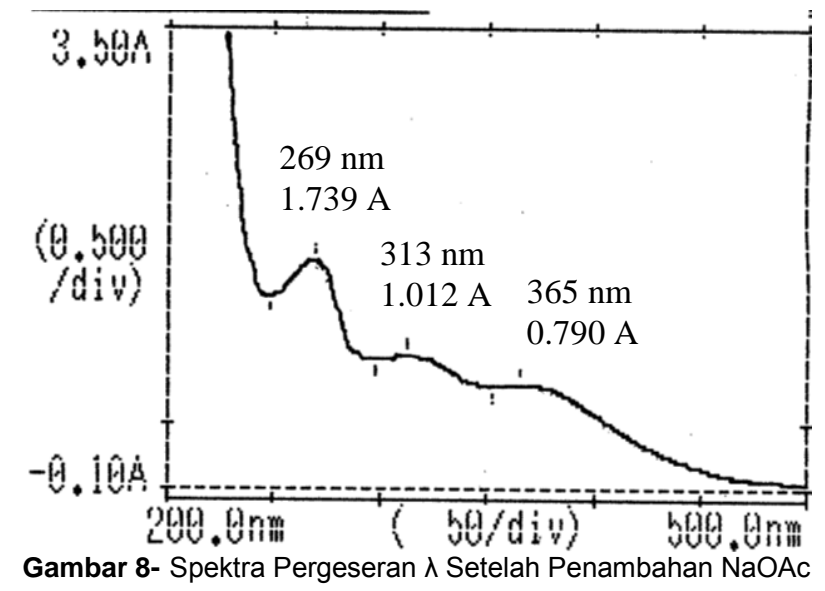

Berdasarkan spektra yang tampak pada Gambar 8 dapat diketahui bahwa terjadi pergeseran batokromik pada pita II sebesar 5 $\mathrm{nm}$ yang menunjukkan adanya gugus $7-\mathrm{OH}$. Spektra yang direkam setelah lima menit

penambahan $\mathrm{NaOAc}$ untuk mengetahui adanya gugus peka basa, yaitu gugus o-diOH yang terletak jauh dari gugus karbonil (gugus keton pada cincin C) jika kekuatan absorbansi berkurang.

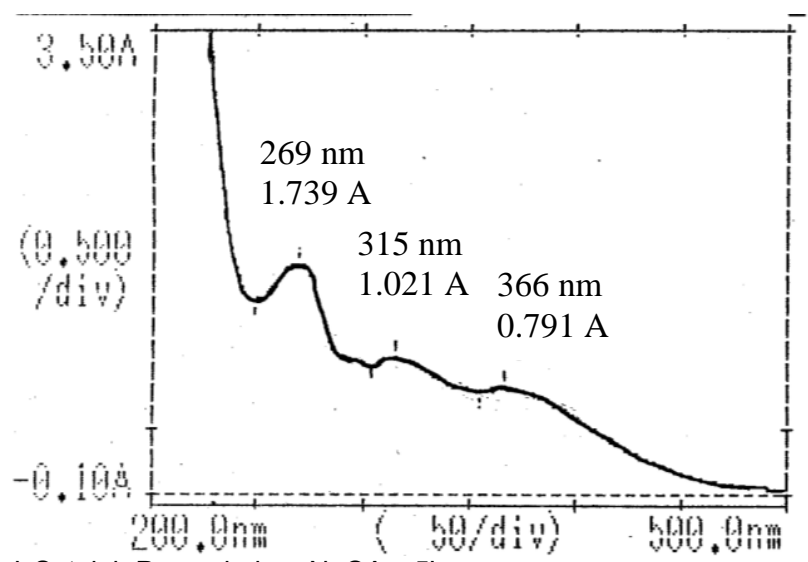

Gambar 9- Spektra Pergeseran $\lambda$ Setelah Penambahan NaOAc, 5

Diketahui dari spektra pada Gambar 9 bahwa tidak ada penurunan absorbansi, berarti tidak terdapat gugus peka basa. Namun hasil ini kurang spesifik karena peran asam borat dalam membentuk kompleks lebih kuat untuk mendeteksi adanya gugus o-diOH, seperti yang dijelaskan pada Gambar10.

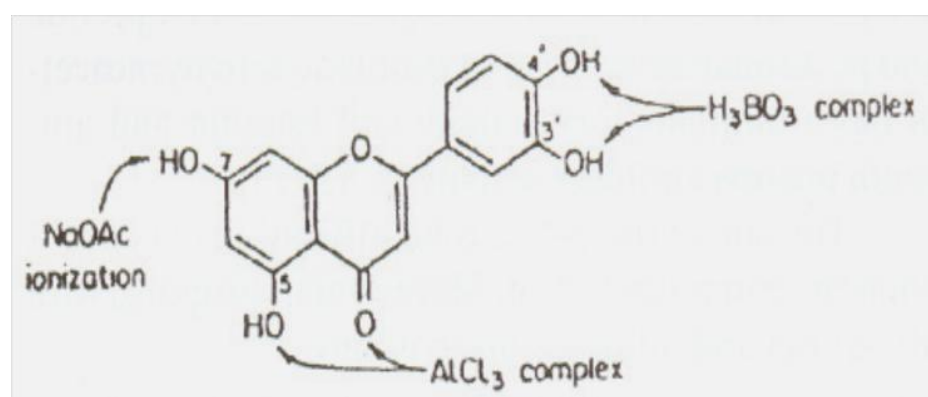

Gambar 10- Mekanisme Reaksi Pereaksi diagnostik NaOAc, $\mathrm{H}_{3} \mathrm{BO}_{3}, \mathrm{AlCl}_{3}$ (Nikolovska-Čoleska, Ž., et all, 1995) 
Penambahan $\mathrm{H}_{3} \mathrm{BO}_{3}$ (asam borat) akan menjembatani kedua gugus hidroksil pada gugus o-diOH sehingga terbentuk kompleks borat. Spektra gambar 10 tampak pergeseran batokromik pita I sebesar $28 \mathrm{~nm}$ menunjukkan adanya gugus o-diOH pada cincin B. Penambahan asam borat dilakukan setelah penambahan natrium asetat karena reaksinya lebih kuat sehingga dapat lebih memantapkan ada/tidaknya dan letak gugus o-diOH.

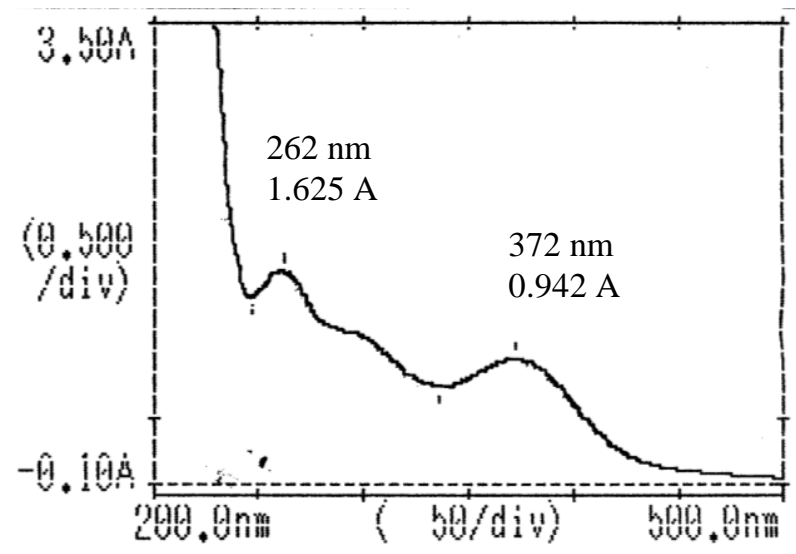

Gambar 11- Spektra Pergeseran $\lambda$ Setelah Penambahan $\mathrm{NaOAc} / \mathrm{H}_{3} \mathrm{BO}$

Isolat dihidrolisis untuk memastikan apakah flavonoidnya terikat gula atau tidak. Hasil elusi pada Gambar 12, walaupun terjadi perubahan harga $\mathrm{Rf}$ isolat terhidrolisis (Rf 1,0 ) lebih tinggi daripada isolat yang belum dihidrolisis pada $\mathrm{UV}_{366} \quad \mathrm{~nm}(\mathrm{Rf} \quad 0,75)$ baik sebelum maupun setelah diuapi ammonia, namun tidak dapat dipastikan adanya gugus gula dalam isolat karena selisih harga $\mathrm{Rf}$ yang kecil.
$\mathrm{UV}_{366}$

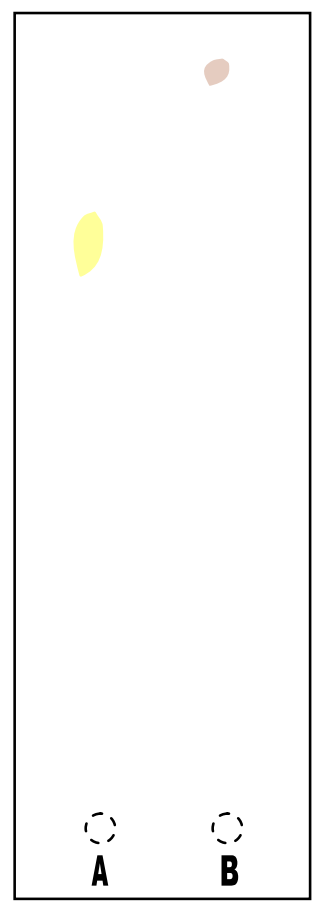

$\mathrm{NH}_{4} \mathrm{OH}+\mathrm{UV}_{366}$

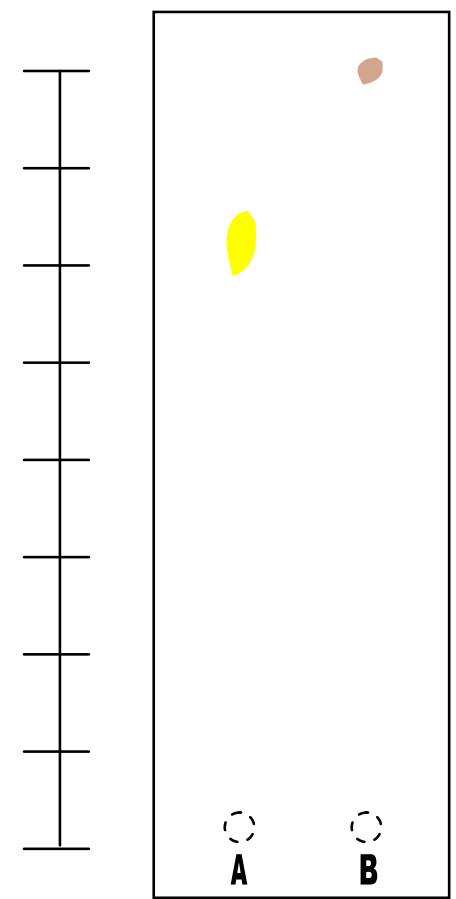

Keterangan :

A : isolat belum dihidrolisis

$\mathrm{B}$ : isolat terhidrolisis

Gambar 12- Kromatogram Uji Aglikon 
Hasil ini ditetapkan berdasarkan kepolaran dan kelarutan isolat terhadap fase gerak, dimana suatu aglikon jauh lebih non polar daripada glikosidanya sehingga akan terelusi lebih cepat dengan perbedaan harga $\mathrm{Rf}$ yang sangat jauh. Rekapitulasi perubahan $\lambda$ tersaji pada tabel 1.

Berdasarkan hasil spektra UV dan kromatogram tersebut di atas, dapat diduga kuat bahwa salah satu jenis flavonoid yang terdapat dalam daun dewandaru yaitu 5,7,3',4'tetra hidroksi flavonol atau kuersetin (Gambar 13). Hasil ini sejalan dengan penelitian Rattmann et al (2012) yang menyatakan bahwa ekstrak etanol $70 \%$ mengandung glikosida myrcetine dan quercetine.

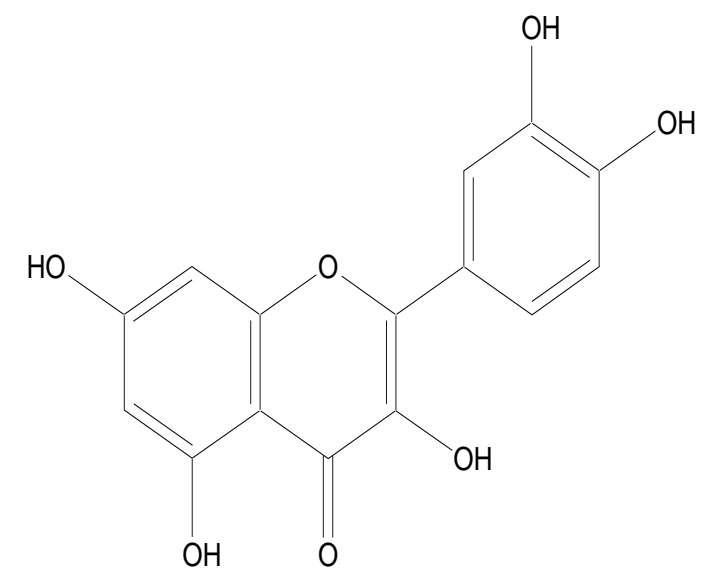

Tabel 1- Rekapitulasi Perubahan $\lambda$ Beserta Perkiraan Gugus pada Struktur Flavonoid dengan Pereaksi diagnostik

\begin{tabular}{|c|c|c|c|c|c|}
\hline \multirow{2}{*}{ Larutan metanol } & \multicolumn{2}{|c|}{$\begin{array}{l}\lambda \text { maks }(\mathrm{nm}) \\
\text { Absorbansi }\end{array}$} & \multicolumn{2}{|c|}{ Pergeseran $\lambda$} & \multirow{2}{*}{ Perkiraan Gugus (Marby et al,1970; Markham, 1998) } \\
\hline & Pita I & Pita II & Pita I & Pita II & \\
\hline Isolat Flavonoid & $\begin{array}{l}344 \\
0.907\end{array}$ & $\begin{array}{l}264 \\
1.662\end{array}$ & & & Flavonol 3-OH tersubstitusi atau Flavon \\
\hline$+\mathrm{NaOH} 2 \mathrm{~N}$ & $\begin{array}{l}351 \\
1.039\end{array}$ & $\begin{array}{l}307 \\
1.072\end{array}$ & +7 & +43 & Ada $\mathrm{OH}$ \\
\hline$+\mathrm{NaOH} 2 \mathrm{~N}\left(5^{\prime}\right)$ & $\begin{array}{l}340 \\
1.076\end{array}$ & - & -4 & - & - \\
\hline$+\mathrm{NaOAc}$ & $\begin{array}{l}365 \\
0.790\end{array}$ & $\begin{array}{l}269 \\
1.739\end{array}$ & +21 & +5 & $7-\mathrm{OH}$ \\
\hline$+\mathrm{NaOAc}\left(5^{\prime}\right)$ & $\begin{array}{l}366 \\
0.791\end{array}$ & $\begin{array}{l}269 \\
1.739\end{array}$ & +22 & +5 & Tidak terdapat gugus peka basa (6,7 atau 7,8 atau $3,4^{\prime}-$ diOH $)$ \\
\hline$+\mathrm{NaOAc} / \mathrm{H}_{3} \mathrm{BO}_{3}$ & $\begin{array}{l}372 \\
0.942\end{array}$ & $\begin{array}{l}262 \\
1.625\end{array}$ & +28 & -2 & o-di OH pada cincin B \\
\hline$+\mathrm{AlCl}_{3}$ & $\begin{array}{l}409 \\
0.703\end{array}$ & $\begin{array}{l}273 \\
1.870\end{array}$ & +65 & +9 & Ada o-di OH \\
\hline$+\mathrm{AlCl}_{3} / \mathrm{HCl}$ & $\begin{array}{l}388 \\
0.719\end{array}$ & $\begin{array}{l}272 \\
1.960\end{array}$ & +44 & +8 & 3-OH dengan atau tanpa $5-\mathrm{OH}$ \\
\hline
\end{tabular}

\section{KESIMPULAN}

Salah satu senyawa flavonoid yang

Gambar 13. Struktur dari 5,7,3',4'-Tetra Hidroksi Flavonol atau Kuersetin terdapat dalam daun dewandaru (Eugenia

\section{DAFTAR PUSTAKA}

Einbond, L.S., Reynertson, K.A., Luo, X., Basile, M.J., dan Kennelly, E.J., 2004, Anthocyanin Antioxidant from Edible Fruits, Food Chem, 23-28.

Haron, N.W., Moore, D.M., Harborne, J.B., 1992, Distribution and Taxonomic Significance of Flavonoids in The Genus Eugenia (Myrtaceae), Biochemical Systematics and Ecology, 20, 226268 cit : Reynertson, K.A., 2007, Phytochemical Analysis of Bioactive Constituents From Edible Myrtaceae Fruits, Dissertation, The City University of New York.

Hutapea, J.R., 1991, Inventaris Tanaman Obat Indonesia III, 45, Depkes RI, Jakarta.

Khotimah, K.D.S., 2004, Uji Aktivitas Antibakteri Ekstrak Kloroform dan Metanol Daun Dewandaru (Eugenia uniflora L.) Terhadap Staphylococcus aereus, Shigella dysentriae, dan Eschericia coli, Skripsi, Fakultas Farmasi, Universitas Muhammadiyah Surakarta.

Mabry, T.J., Markham, K.R., dan Thomas, M.B., 1970, The Systematic Identification of Flavonoid, 3-56, 165-171, Spinger-Verlag, New York, Heidelberg, Berlin.

Markham, K.R., 1988, Cara Mengidentifikasi Flavonoid, diterjemahkan oleh Kosasih Padmawinata, 19-21, 31, 41-47, 65-75, Penerbit ITB, Bandung. 
Morton, J.F., 1987, Surinam cherry, (online), http://www.hort.purdue.edu/ newcrop/default.html, diakses tanggal 16 Maret 2007.

Nikolovska-Čoleska, Ž., Dorevski, K., Klisarova, L., Šuturkova-Milošević, L., 1995, Identification of Phenolic Constituents Isolate from Macedonian Propolis, Bulletin of the Chemists and Technologists of Macedonia, Vol. 14, No. 1, 13 -17.

Reynertson, K.A. and Kennelly, E.J., 2001, Antioxidant Polyphenols from Fruits of the Myrtaceae: A Chemotaxonomic and Ethnomedical Approach to Discovery, Building Bridges with Traditional Knowledge II, The Society for Economic Botany, $42^{\text {nd }}$ Annual Meeting and The International Society for Ethnopharmacology, Honolulu.

Schmeda-Hirschmann, G., Theoduloz, C., Franco, L., Ferro, E., Rojas de Arias, A., 1987, Preliminary Pharmacological Studies on Eugenia uniflora Leaves: Xanthine Oxidase Inhibitory Activity. Journal of Ethnopharmacology, 21, 183-186 cit : Reynertson, K.A., 2007, Phytochemical Analysis of Bioactive Constituents From Edible Myrtaceae Fruits, Dissertation, The City University of New York.

Utami, W., Da'l, M., dan Sofiana., 2005, Aktivitas Penangkap Radikal dengan Metode DPPH serta Penetapan Kandungan Fenol dan Flavonoid dalam Ekstrak Kloroform, Ekstrak Etil Asetat, Ekstrak Etanol Daun Dewandaru (Eugenia uniflora L.), Pharmacon, Vol 6, No.1, 5-9 